4. Система авіаційної безпеки // Міністерство внутрішніх справ України. URL: https://www.kmu.gov.ua/news/do-kincya-roku-v-ukrayinipovnocinno-zapracyuye-sistema-aviacijnoyi-bezpeki-arsen-avakov

5. Commission on accreditation of Medical Transport System, 2021. URL: https://www.camts.org

6. Ban on surprise medical bills could reshape U.S. air ambulance industry // Vertical. URL: https://verticalmag.com/features/surprise-medicalbills-ban-could-reshape-air-ambulance-industry/

7. До лікарні - вертольотом. В Україні «стартувала аеромедична евакуація» // BBC News Україна, 2021. URL: https://www.bbc.com/ ukrainian/features-56702650

8. Єдина система авіаційної безпеки та цивільного захисту MBC України, 2021. URL: https://mvs.gov.ua/uk/press-center/infographics/ jedina-sistema-aviaciinoyi-bezpeki-ta-civilnogo-zaxistu-mvs-ukrayini-20795

DOI https://doi.org/10.30525/978-9934-26-172-5-25

\title{
ОПТИМІЗАЦІЯ ТРАНСПОРТУВАННЯ МАСОВОЇ СИРОВИНИ ДО ПРОМИСЛОВИХ ПІДПРИЕМСТВ У ПЕРІОД НЕГАТИВНИХ ТЕМПЕРАТУР
}

\author{
Дженчако В. Г. \\ кандидат технічних наук, \\ старший викладач кафедри транспортних технологій підприємств \\ ДВНЗ «Приазовський державний технічний університету \\ м. Маріуполь, Донещька область, Украӥна
}

Для визначення ритмічного підведення маршрутних поїздів зі змерзлою сировиною в пункти призначення і вивантаження їх у встановлені терміни вся робота по навантаженню, просуванню i вивантаженню маршрутних поїздів повинна бути організована за єдиними транспортно - вантажно - вивантажувальними графіками. Вихідними даними при організації цієї роботи повинні бути розміри відвантаження відповідного виду сировини (залізорудного концентрату, агломераційної руди, кам'яного вугілля та ін.). Розміри споживання цієї сировини в пунктах переробки (металургійні комбінати), дальність перевезення сировини до найбільш масових споживачів, ритмічність навантаження і вивантаження сировини (темп навантаження). 
Нормальна робота підприємств, які споживають масову сировину, з урахуванням запасів, вироблених в літній період, буде забезпечуватися за умови рівномірного надходження цісї сировини у період негативних температур в кількості, що відповідає потребі даного підприємства [1, с. 91-93]. Кількість маршрутних поїздів, завантажених сировиною, що перебувають в обігу, буде залежати від обраного способу забезпечення навантаження порожніми вагонами. Якщо для транспортування масової сировини будуть використані замкнуті маршрутні поїзди, то число їх для транспортування цісї сировини на адресу одного певного підприємства дорівнюватиме:

$$
n_{1}=\frac{Q_{1}^{c}}{Q_{1}^{M} \cdot T_{1}^{M}},
$$

де, $Q_{1}^{c}$ - добове споживання сировини переробними підприємствами, т; $Q_{1}^{n}$ - маса сировини нетто у одному маршрутному поїзді, т; $T_{1}^{M}$ - час обороту одного маршрутного поїзду, діб.

Інтервали прибуття і подачі маршрутних поїздів під вивантаження на переробних підприємствах встановлюють 3 урахуванням продуктивності підприємства за обсягом продукції, що випускається і рівномірності роботи його протягом доби.

Виходячи 3 цих міркувань, інтервали прибуття та вивантаження маршрутних поїздів із сировиною визначають за формулою:

$$
I_{\max }=\frac{1440 \cdot Q^{M}}{Q^{c}}
$$

де, $I_{\max }$ - максимально можливий інтервал, протягом якого повинні бути виконані всі операції з маршрутними поїздами, діб.

$Q^{M}$ - маса сировини, що перевозиться в одному маршрутному поїзді, т;

$Q^{c}$ - добове споживання масової сировини, т.

У період негативних температур, коли масова сировина прибуває у змерзлому стані, при визначенні часу обробки маршрутного поїзда в пункті вивантаження в необхідних випадках треба враховувати час, що витрачається на виконання операцій 3 розморожування змерзлої сировини.

Загальна кількість маршрутних поїздів, що відвантажуються в пунктах виробництва масової сировини, і отже, інтервали (темп) навантаження, коли шахти або кар'єри обслуговують кілька 
промислових підприємств - споживачів, визначають, виходячи 3 суми маршрутних поїздів, що відвантажуються для кожного підприємства.

Рівномірне підведення маршрутних поїздів в пункти вивантаження забезпечують з урахуванням кількості маршрутних поїздів, спрямованих на адресу одержувача (підприємства) і відстані перевезення. Інтервали прибуття маршрутних поїздів на адресу одного одержувача визначають за формулою (2). Для ув'язки і забезпечення рівномірності прибуття маршрутних поїздів 3 масовою сировиною, що відвантажується з одного фронту навантаження в усі пункти призначення, доцільно будувати спеціальні графіки.

Забезпечення рівномірного підведення маршрутних поїздів 3 масовою сировиною протягом доби до пунктів вивантаження безсумнівно сприятливо вплине на прискорення вивантаження, так як це майже повністю виключить непродуктивні простої завантажених вагонів в пунктах вивантаження або затриманих на підходах до них із за розморожування раніше підведених завантажених вагонів 3 порушенням встановленого режиму. Порушення ритмічного підведення навантажених вагонів у період негативних температур зовнішнього повітря і тривалих затримок в очікуванні подачі під вивантаження буде неминуче супроводжуватися посиленням змерзання і ускладненням умов вивантаження. Якщо при цьому вагони під вивантаження подавати 3 дотриманням черговості їх прибуття, то усі вагони будуть затримані в очікуванні вивантаження, а масова сировина в них під впливом негативних температур довкілля буде змерзатися до такої ж міри, як і в раніше прибулих вагонах [2, с. 262 - 268].

При певних умовах (велике скупчення вагонів зі змерзлою сировиною в очікуванні вивантаження, негативні температури довкілля, дальність транспортування та ін.) доцільно в першу чергу вивантажувати вагони 3 підходу, а раніше прибулі і затримані вагони 3 вельми сильно змерзлою сировиною подавати під вивантаження в міру оперативних можливостей і звільнення секцій гаражів розморожування. При такому варіанті абсолютний простій вагонів під вивантаженням i труднощі з вивантаженням будуть безсумнівно менше. Цей захід буде ефективним у всіх випадках, коли змерзлу сировину перевозять у період негативних температур довкілля (нижче $-10^{\circ} \mathrm{C}$ ) і на порівняно короткі відстані. Якщо у новоприбулих вагонах за час транспортування вся сировина буде характеризуватися однаковим ступенем змерзання, як і в вагонах, які прибули раніше, то рекомендований захід належного ефекту не дає. Доцільність здійснення викладених заходів повинна бути підкріплена кожен раз елементарними розрахунками з урахуванням виниклих умов (кількість затриманих вагонів в очікуванні 
вивантаження, витрати часу на розморожування масової сировини поточного надходження і яка прибула раніше).

Організаційні заходи щодо оптимізації транспортування масової сировини до промислових підприємств у період негативних температур:

- максимальне охоплення перевезень масової сировини, що змерзається маршрутними поїздами й збільшеними групами вагонів;

- організація руху маршрутних поїздів зі змерзлою сировиною за розробленими графіками;

- організація регулярної і точної інформації вантажоодержувачів про відвантаженої на їхню адресу сировини і часу надходження вагонів 3 цією сировиною в пункти призначення під вивантаження, а також відправників - про стан справ із вивантаженням у одержувачів i температурних умовах по шляху проходження у одержувачів;

- регулювання навантаження по призначеннях 3 урахуванням очікуваних частих змін температури довкілля;

- зниження навантаження окремої сировини, що змерзається, за рахунок збільшення навантаження незамерзаючою сировиною;

- переадресування маршрутних поїздів 3 масовою сировиною, що змерзається під час транспортування [3, с. 224 - 237].

\section{Література:}

1. Турпак С. М., Кузькін О. Ф., Грицай С. В. Імітаційна модель роботи транспорту металургійного підприємства у зимовий період. Нові матеріали $i$ технологї в металургї та машинобудуванні. 2009. № 1. С. 91-93.

2. Турпак С. М. Оптимізація транспортно-технологічних процесів при змерзанні вантажів. Вісник Східноукраӥнського національного університету імені Володимира Даля. 2014. № 3. С. 262-268.

3. Дженчако В.Г. Підвищення ефективності перевезення масової сировини на промислові підприємства у зимовий період. Міжвузівський тематичний збірник наукових працьь. ДВНЗ «ПДТУ». Маріуполь. 2019. № 21. C. 224-237. 